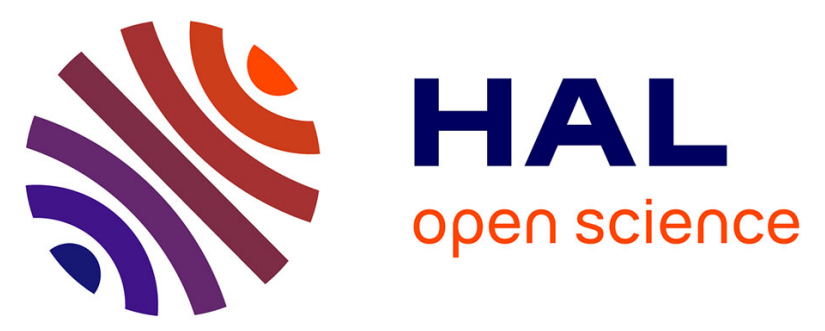

\title{
Salmeterol restores secretory functions in cystic fibrosis airway submucosal gland serous cells.
}

\author{
Franck Delavoie, Michael Molinari, Magali Milliot, Jean-Marie Zahm, \\ Christelle Coraux, Jean Michel, Gerard Balossier
}

\section{- To cite this version:}

Franck Delavoie, Michael Molinari, Magali Milliot, Jean-Marie Zahm, Christelle Coraux, et al.. Salmeterol restores secretory functions in cystic fibrosis airway submucosal gland serous cells.. American Journal of Respiratory Cell and Molecular Biology, 2009, 40 (4), pp.388-97. 10.1165/rcmb.20080037OC . inserm-00336161

\section{HAL Id: inserm-00336161 https://www.hal.inserm.fr/inserm-00336161}

Submitted on 3 Nov 2008

HAL is a multi-disciplinary open access archive for the deposit and dissemination of scientific research documents, whether they are published or not. The documents may come from teaching and research institutions in France or abroad, or from public or private research centers.
L'archive ouverte pluridisciplinaire HAL, est destinée au dépôt et à la diffusion de documents scientifiques de niveau recherche, publiés ou non, émanant des établissements d'enseignement et de recherche français ou étrangers, des laboratoires publics ou privés. 
Salmeterol restores secretory functions in cystic fibrosis airway submucosal gland serous cells

Franck Delavoie ${ }^{1,2,3}$, Michael Molinari ${ }^{4}$, Magali Milliot ${ }^{3}$, Jean-Marie Zahm ${ }^{3}$, Christelle Coraux $^{3}$, Jean Michel ${ }^{1,2}$ and Gérard Balossier ${ }^{1,2}$

${ }^{1}$ INSERM, UMRS 926, Reims, F-51685, France $;{ }^{2}$ Univ Reims Champagne-Ardenne, Laboratoire de Microscopie Electronique Analytique, Reims, F-51097, France ; ${ }^{3}$ INSERM, UMRS 903, Reims, F-51092, France; ${ }^{4}$ Univ Reims Champagne-Ardenne, laboratoire des microscopies et nanomatériaux, Reims, F-51097, France.

\section{Corresponding author:}

DELAVOIE Franck, Ph.D.

INSERM UMRS 926, Laboratoire de Microscopie Electronique Analytique

21 rue Clément Ader, B.P. 138, 51685 REIMS Cedex 2 France.

Phone: 333267707 24; Fax: 333260519 00; E-mail: franck.delavoie@univ-reims.fr 


\section{ABSTRACT}

The activity of the cystic fibrosis transmembrane conductance regulator (CFTR) can be mediated by surface $G$ protein-coupled receptors such as the beta2-adrenergic receptor. In this study, we explored the effect of a long-acting beta2-adrenergic agonist, salmeterol, on the CFTR-dependent secretory capacity of a human CF tracheal gland serous cell line (CF-KM4), homozygous for the delF508 mutation. We showed that, compared to the untreated CF serous cells, a $24 \mathrm{~h}$ pre-incubation period with $200 \mathrm{nM}$ salmeterol induced an $83 \%$ increase in delF508-CFTR-mediated chloride efflux. The restoration of the bioelectric properties is associated with increased apical surface pool of delF508-CFTR. Salmeterol induced a decrease in ion concentration and an increase in the level of hydration of the mucus packaged inside the CF secretory granules. The effects of salmeterol are not associated with a persistent production of cAMP. Western blotting on isolated secretory granules demonstrated immunoreactivity for CFTR and lysozyme. In parallel, we measured by AFM an increased size of secretory granules isolated from CF serous cells compared to non-CF serous cells (MM39 cell line) and showed that salmeterol was able to restore a CF cell granule size similar to that of non-CF cells. To demonstrate that the salmeterol effect was a CFTR-dependent mechanism, we showed that the incubation of salmeterol-treated CF serous cells with CFTRinh172 suppressed the restoration of normal secretory functions. The capacity of salmeterol to restore the secretory capacity of glandular serous cells suggests that it could also improve the airway mucociliary clearance in patients with $\mathrm{CF}$.

Keywords: Submucosal gland serous cell, secretory granule, salmeterol, CFTR. 


\section{Introduction}

Cystic fibrosis (CF) is a lethal autosomal recessive genetic disease (1) associated with hyperviscous and dehydrated airway surface liquid, airway inflammation and chronic bacterial infection (2). This genetic defect is due to mutations of the single gene encoding the Cystic Fibrosis Transmembrane conductance Regulator (CFTR), an epithelial chloride channel. The most common mutation is the deletion of the phenylalanine amino acid at position 508 (delF508-CFTR) that reduces the export and stabilization of CFTR to the apical plasma membrane (3). CFTR is expressed in the acinar serous cells of the airways $(4,5)$ and participates in fluid secretion that contains ions, water and proteins (6). Thus, CFTR regulates secretion of mucins and serous proteins in epithelial cells (7) by secretagogues that elevate intracellular cAMP resulting in protein kinase A-dependent phosphorylation (8, 9). Regulation of the CFTR activity is dependent on the activation of surface G protein-coupled receptors, such as the beta2-adrenergic receptor which is expressed in airway epithelial cells $(10,11)$ and coupled to adenylate cyclase (12). However, CF airway epithelial cells were shown to be unstimulated by a short-acting beta-adrenergic agonist like isoproterenol $(13,14)$. In a previous study, we showed that the absence of CFTR-mediated chloride efflux in CF serous cells was associated with an increased ion concentration and decreased hydration of mucus inside secretory granules with, in parallel, a defective mucus post-exocytosis expansion dynamics (15). Among the recent therapeutic strategies in CF, some of them, based on CFTR correctors or potentiators, target the underlying defect (16). Having previously shown that beta2-AR activation regulates the cystic fibrosis transmembrane conductance regulator (CFTR) chloride channel (11), we hypothesize that a long-acting beta2-adrenergic agonist like salmeterol could correct this defect. The aim of the present study was to explore the effect of salmeterol on the forskolin activated-chloride efflux in a human CF tracheal gland serous cell line (CF-KM4), derived from a delF508 homozygous patient (17). We also 
examined the hydration and the ion composition of secretory granule content in salmeteroltreated CF serous cells in relation with the size and post-exocytosis expansion dynamics of secretory granules.

\section{Material and Methods}

Culture of human airway glandular epithelial cells - Non-CF and CF serous cell lines derived from primary cultures of human tracheal gland serous cells and kindly provided by M. Merten were used in the present study. The MM39 cells (18) express wt-CFTR and the CFKM4 (17) cells are homozygous for the delF508 mutation. The airway serous cells were cultured at $37^{\circ} \mathrm{C}$ under a $5 \% \mathrm{CO}_{2}$ atmosphere on Petriperm dishes (Vivascience, Palaiseau, France) or on glass bottom dishes (MatTek, Ashland, USA) coated with 2\% type I collagen. The cells were grown in Dulbecco's modified Eagle's medium (DMEM)/F-12 (Sigma Chemical Co., St Louis, Mo.) supplemented with $1 \%$ Ultroser G serum substitute (Biosepra, Villeneuve, La Garenne, France), glucose (10 g/l), sodium pyruvate $(0.33 \mathrm{~g} / \mathrm{l})$, penicillin (100 IU/ml), streptomycin $(100 \mu \mathrm{g} / \mathrm{ml})$ and amphotericin B $(2 \mu \mathrm{g} / \mathrm{ml})$. Cells were seeded at a density of $10^{6}$ cells $/ \mathrm{ml}\left(10^{5}\right.$ cells $\left./ \mathrm{cm}^{2}\right)$ and grown to confluence to allow polarization and differentiation.

Preparation of salmeterol and ICI 118551 - Salmeterol hydroxynaphthoate, provided by GlaxoSmithKline, was dissolved in a minimum amount of glacial acetic acid (30 $\mu 1)$ and then diluted to a concentration of $20 \mathrm{mM}$ in PBS and kept at $-20^{\circ} \mathrm{C}$. Solutions were buffered to $\mathrm{pH}$ 7.4. A highly specific $\beta_{2}$ receptor antagonist, ICI 118551 hydrochloride (Tocris, Ballwin, MO, USA) was prepared as a $10 \mathrm{mM}$ stock solution in deionized water and kept at $-20^{\circ} \mathrm{C}$. As 
previously described (19), ICI 118551 was used at a final concentration of $200 \mathrm{nM}$ in complete medium.

Treatment of human airway glandular epithelial cells with salmeterol - After cell confluence was reached, the culture medium was changed to a serum-free medium containing salmeterol at a final concentration of 2,20 or $200 \mathrm{nM}$ and the cells were incubated for a further $24 \mathrm{~h}$ period. To demonstrate that the effect of salmeterol was specific, cells were incubated with $200 \mathrm{nM}$ ICI 118551 hydrochloride in the presence of $200 \mathrm{nM}$ salmeterol. To inhibit CFTR functionality, the cells were incubated for $1 \mathrm{~h}$ in serum substitute-free culture medium containing $5 \mu \mathrm{M}$ CFTR-inh172 (Calbiochem, San Diego, USA), which is a thiazolidinone CFTR inhibitor (20).

SPQ studies of halide efflux in human airway glandular epithelial monolayer - Cells cultured on glass bottom dishes were incubated for 20 min at $37^{\circ} \mathrm{C}$ with the halide-quenched dye 6-methoxy-N-(3-sulfopropyl)quinolinium (SPQ) in a chloride buffer solution (130 mM $\mathrm{NaCl}, 2.4 \mathrm{mM} \mathrm{K}_{2} \mathrm{HPO}_{4}, 10 \mathrm{mM}$ D-glucose, $1 \mathrm{mM} \mathrm{CaSO}$, $1 \mathrm{mM} \mathrm{MgSO}$ and $10 \mathrm{mM}$ Hepes) made hypotonic by adding an equivalent volume of water. Thereafter, the hypotonic chloride buffer was replaced by an isotonic chloride buffer for $15 \mathrm{~min}$ and then by a nitrate buffer in which the $\mathrm{NaCl}$ was replaced by $130 \mathrm{mM}$ of $\mathrm{NaNO}_{3}$. The culture dish was placed on the heated stage of an inverted microscope (TE 300, Nikon, Champigny sur Marne, France). After $30 \mathrm{sec}$, amiloride $(10 \mu \mathrm{M})$, and $1.5 \mathrm{~min}$ later, forskolin $(25 \mu \mathrm{M})$, were added to the nitrate buffer. Throughout the experimental process, fluorescence images $\left(\lambda_{\mathrm{ex}}\right.$ at $365 \mathrm{~nm}$ and $\lambda_{\mathrm{em}}$ at $395 \mathrm{~nm}$ ) were recorded every $15 \mathrm{sec}$ using a Micromax CCD camera and the Metafluor software (Roper Scientific, Evry, France). As previously described (21), chloride efflux was 
calculated by measuring the variation in SPQ fluorescence over a 1.5 min incubation period $(\Delta \mathrm{F} / \Delta \mathrm{t})$ following the addition of forskolin.

Bioelectric properties measurements with Ussing chambers The cells were cultured on Snapwell inserts (Corning Incorporated, Lowel, MA) that contain a $12 \mathrm{~mm}$ diameter tissue culture membrane supported by a detachable ring. Once cells reached confluence (5-6 days after plating), they were incubated with salmeterol $(200 \mathrm{nM})$ for $24 \mathrm{~h}$ in non-supplemented culture medium or in culture medium alone (control cells). After $24 \mathrm{~h}$ of salmeterol treatment, the ring-supported membrane was placed into an Ussing chamber and the bioelectric properties measured with a voltage clamp instrument (DVC-1000, World Precision Instruments, Aston, UK). The cells were exposed on each surface to $6 \mathrm{ml}$ of Hanks balanced salt solution (HBSS) gassed with $95 \% \mathrm{O}_{2} / 5 \% \mathrm{CO}_{2}$. Experiments were conducted at $37^{\circ} \mathrm{C}$. The short-circuit current (Isc) was monitored continuously and transepithelial resistance was determined by clamping the potential difference to $30 \mathrm{mV}$, recording the defection in Isc and applying Ohm's law. Pharmacologic agents were added to the apical bathing solution and bioelectric activity was monitored thereafter. Amiloride $(10 \mu \mathrm{M})$, forskolin $(25 \mu \mathrm{M})$ and CFTR-inh172 $(5 \mu \mathrm{M})$ were added sequentially. Changes in Isc were calculated as the variations between the values measured immediately before the addition of reagents and the values corresponding to the plateau phase after the addition of reagents. Three independent experiments with cells pre-incubated with salmeterol were conducted in parallel with control cells.

Immunofluorescence microscopy - The cells grown to confluence on glass coverslip coated with $2 \%$ type I collagen were rinsed in PBS buffer and fixed in methanol $\left(10 \mathrm{~min}\right.$ at $\left.-20^{\circ} \mathrm{C}\right)$. They were then treated with $3 \%$ BSA before addition of primary and secondary antibodies 
and washed three times with PBS. All antibodies were in $1 \%$ BSA solution. Monolayers were sequentially incubated with murine anti-CFTR (24-1, 1:100 dilution, R et D Systems, Lille, France) overnight at $4^{\circ} \mathrm{C}$ and with an Alexa Fluor 488 anti-mouse IgG antibody (Molecular Probes, Eugene, Oregon) for 1 hour at room temperature. Cells were then incubated with dapi (Molecular Probes) for nucleus staining and after a final PBS wash, they were mounted in Aquamount (VWR, Fontenay sous Bois, France) onto microscope slides. Slides were observed under an AxioImager fluorescence microscope (Zeiss, Le Pecq, France) equipped with an apotome device (Zeiss). Images were recorded with a CCD video camera (Coolsnap, Roper Scientific, Tucson, AZ) at 21 successive z levels $(1 \mu \mathrm{m}$ between each z level $)$ at $\mathrm{x} 40$ magnification.

Measurement of intracellular cAMP - We used cAMP enzyme immunoassays (Biotrak enzymeimmunoassay system, Amersham Pharmacia Biotech, Les Ullis, France) to measure the intracellular cAMP content in the control and the salmeterol-treated CF-KM4 cells under basal condition and after acute amiloride/forskolin stimulations $(\sim 1 \mathrm{~min})$. The analyses were performed according to standard manufacturer's protocol.

Cryopreparation of cells - The cryopreparation of the cells was performed as described previously (15). Briefly, the CF-KM4 cells cultured on petriperm dishes were cryofixed using liquid ethane cooled by liquid nitrogen. The sample was transferred to a cryo-ultramicrotome and cryosections then cut and deposited on formvar/carbon film supported by a copper grid. The cryosections were transferred in a frozen hydrated state to a Scanning Transmission Electron Microscope (STEM CM30, Philips, Limeil-Brevannes, France) equipped with an energy-dispersive X-ray spectrometer and fitted with an EDAX $30 \mathrm{~mm}^{2} \mathrm{Si}(\mathrm{Li}) \mathrm{R}-\mathrm{SUTW}$ 
detector and a GATAN ENFINA dark field detector. The sample was freeze-dried and cooled to $-175^{\circ} \mathrm{C}$ prior to the analysis of ion and water content.

Ion and water content analysis - Ion and water content was determined as described previously (15). Briefly, we used electron probe X-ray microanalysis and a quantitative dark field intensity technique with a scanning transmission electron microscope (STEM CM30, Philips) for measuring the in situ ion and water content in the cytoplasm and in the secretory granules of entire cryofixed cells. In practice, the cryosection of cells irradiated by an electron beam emits an X-ray signal. The emission spectrum (Fig. 4A) corresponds to the counting of X-rays emitted according to their energy. If the cryosections are sufficiently thin $(<1 \mu \mathrm{m})$, the intensity ratio specific peak/background (method of the Hall's continuum), allows the measurement of the concentrations of all the light elements detected in the spectrum (22). To obtain the exact value of the mass concentrations (mmol/kg dry weight) of the light elements of interest ( $\mathrm{Na}, \mathrm{Mg}, \mathrm{S}, \mathrm{Cl}$ and $\mathrm{K}$ ), we measured under the same experimental conditions, the ratio specific peak/background of the elements obtained compared with standard samples of known mass concentrations. The mass concentrations in millimoles per kilogram of dry matter $(C d)$ can be converted into millimoles per liter of water $\left(C_{h}\right)$ by using the equation $C_{h}=$ $\{(100-\mathrm{L}) / \mathrm{L}\} \mathrm{X} \mathrm{Cd}$ where $\mathrm{L}$ is the percentage of water determined by quantitative dark field imaging. The water mass content was deduced from the complement to $100 \%$ of dry mass content measured on the dark field images. We developed an original intracellular water content quantification method with high spatial resolution $(<30 \mathrm{~nm})$ based on dark field imaging. A hydrated cryosection contains a dry mass percentage (M) and its water complement $(\mathrm{L})$ with $\mathrm{L}+\mathrm{M}=100 \%$. During biological sample freeze-drying inside the microscope column, water (under amorphous ice sate) is sublimed and then the relative dark field intensity becomes directly proportional to the percentage of sample dry mass. By image 
processing, we obtained a parametric image in which the grey levels were proportional to the mass water content (L). The intracellular water content (L) was calculated by comparisons with relative dark field intensities of standard samples with known water content (23). According to the different experimental conditions, 36 to 65 secretory granules from 14 to 21 cells were analyzed. Prior to the quantitative X-ray microanalysis, we showed that the $\mathrm{K} / \mathrm{Na}$ ratio in the nucleus and in the cytoplasm was higher than 5 , which is a characteristic of alive confluent cells (24).

Phase-contrast videomicroscopy - The dynamics of secretory granule post-exocytosis expansion was assessed by phase-contrast videomicroscopy as described previously (15). Briefly, CF-KM4 cells, cultured on a $35 \mathrm{~mm}$ collagen I-coated dish, were placed in the environmental chamber $\left(37^{\circ} \mathrm{C}, 5 \% \mathrm{CO}_{2}\right)$ of an inverted microscope (Axioplan 200, Zeiss, Le Pecq, France) and phase-contrast images were recorded every $30 \mathrm{sec}$ for $2 \mathrm{~h}$. From time-lapse images collected in non-stimulated basal condition, we measured the variations of the postexocytosis granule diameter versus time and we calculated the standard deviation of the mean diameter, which represents the expansion index. Thus, a high expansion index corresponded to a progressive increase followed by a decrease of the post-exocytosis granule diameter that represents normal mucus expansion. In contrast, a small expansion index corresponded to a constant post-exocytosis granule diameter that represents deficient mucus expansion.

Isolation of secretory granules - Secretory granules were isolated from MM-39 and CFKM4 cell lines cultured in a collagen-coated T75 flask. After cell confluence was reached, the cells were detached by trypsin digestion and centrifuged for 5 min to obtain a cell pellet. The pellet was suspended in $5 \mathrm{ml}$ ice-cold PBS buffer and homogenized using a glass homogenizer. To obtain pure and damage-free granules, we used a gradient of Percoll 
(Amersham, Les Ulis, France) step in the isolation procedure as described by De Lisle et al (25). Briefly, the cell homogenate was layered over a three-step gradient of Percoll (60\%, $40 \%$ and $20 \%$ ) and was centrifuged for $30 \mathrm{~min}$ at 10,000g in a type $75 \mathrm{Ti}$ rotor on a $\mathrm{L} 7-65$ ultracentrifuge (Beckman Coulter, Villepinte, France). Pure secretory granules were obtained as a translucent pellet at the bottom of the tube.

Western blot analysis - Equal amounts of proteins from isolated secretory granules were separated by electrophoresis on 7.5\% SDS-polyacrylamide gels and electroblotted to PVDF membranes using $100 \mathrm{~V}$ for $1 \mathrm{~h}$ at $4^{\circ} \mathrm{C}$. Membranes were incubated for $1 \mathrm{~h}$ in a blocking buffer containing $5 \%$ non-fat dry milk in PBS with $0.1 \%$ Tween 20 , then overnight with 0.1 $\mu \mathrm{g} / \mathrm{ml}$ of anti-CFTR antibody (24-1, R\&D Systems, Lille, France) or $7 \mu \mathrm{g} / \mathrm{ml}$ of antilysosyme muramidase (EC 3.2.1.17, Dako, Trappes, France) and finally with secondary peroxidase-conjugated IgG. Blots were revealed by using an ECL+ kit (GE Healthcare, Little Chalfont, UK) and analyzed by densitometry with a Fuji Las-1000 (Raytest, Courbevoie, France).

Electron microscopy of isolated secretory granules - Pellet of pure secretory granules was resuspended for $4 \mathrm{~h}$ at $4^{\circ} \mathrm{C}$ in PBS buffer containing $4 \%$ paraformaldehyde. After fixation, the secretory granules were centrifuged and the pellet embedded in EPON resin (Kit AGAR 100 RESIN) and sectioned. The ultrathin sections were transferred to collodion/carbon coated cupper grids and examined in the STEM CM30 electron microscope.

Atomic force microscopy - Pellets of pure secretory granules were plated on freshly cleaved mica sheet and air dried overnight at $37^{\circ} \mathrm{C}$. Then, the secretory granules were imaged using a multimode Nanoscope III (Veeco, Dourdan, France) in tapping mode. A silicon 
nitride tip (Veeco, France) with a spring constant of $46 \mathrm{~N} . \mathrm{m}^{-1}$ and a frequency of $300 \mathrm{kHz}$ was used in the study. AFM images were generated with a scan rate of $1 \mathrm{~Hz}$ and 256 lines per image. Experiments were carried out at constant room temperature. During the scans, proportional and integral gains were increased to the value just below the point at which the feedback started to oscillate. Images were processed by flattening to remove background slopes.

Evaluation of secretory granule size -Since the density of granules is too high to determine the size of individual granules from AFM images, we evaluated the mean size of granules through a statistical estimation. For this, we selected an approach based on the image auto-correlation function (ACF). The ACF of an image is a two-dimensional function $\operatorname{ACF}(\Delta x, \Delta y)$ that shows a maximum value at $\Delta x=\Delta y=0$ and decreases as $\Delta x$ or $\Delta y$ increases. The speed of decrease is larger for images of small particles than for images of large particles. Thus, we could use the half-width at half-height of the ACF as an estimate of the size of secretory granules.

Statistical Analysis - Data are reported as means \pm SEM. Statistical significance was determined by ANOVA test. A probability level of $\mathrm{p}<0.05$ was considered significant. 


\section{RESULTS}

Salmeterol activates wt-CFTR and delF508-CFTR in human airway glandular epithelial monolayers - In order to evaluate the effect of salmeterol on CFTR functionality, we performed chloride efflux experiments using the halide-sensitive dye SPQ on cells preincubated for $24 \mathrm{~h}$ with salmeterol (0 (Untr), $2 \mathrm{nM}, 20 \mathrm{nM}, 200 \mathrm{nM})$. Figure 1A shows representative greyscale fluorescent images of SPQ-loaded CF serous cells after pre-treatment with salmeterol followed by amiloride and forskolin exposure. Likewise, the graph in figure 1A shows chloride efflux time courses for SPQ assays that allow comparison between untreated and salmeterol-treated CF serous cells. We observed (Fig. 1B, white bars) that salmeterol at $200 \mathrm{nM}$ significantly increased $(\mathrm{p}<0.001)$ by $83 \%$ the forskolin-activated chloride efflux compared to untreated CF cells (Fig. 1B, black bar). In subsequent experiments, $\mathrm{CF}$ serous cells were incubated in the presence of $200 \mathrm{nM}$ salmeterol for different incubation times ( $4 \mathrm{~h}, 16 \mathrm{~h}$ and $24 \mathrm{~h})$. Salmeterol increased significantly $(\mathrm{p}<0.001)$ by $83 \%$ the forskolin-activated chloride efflux after $16 \mathrm{~h}$ and $24 \mathrm{~h}$ of incubation (Fig. 1C,) compared to untreated CF cells. We noticed that the $24 \mathrm{~h}$ pre-incubation of the non-CF serous cells with $200 \mathrm{nM}$ salmeterol induced a $53 \%$ increase of the forskolin-activated chloride secretion (data not shown). In CF serous cells, the chloride secretion was increased by salmeterol to a similar level as $\mathrm{CF}$ cells cultured at $27^{\circ} \mathrm{C}$ (Fig. $1 \mathrm{C}, 27^{\circ} \mathrm{C}$ ), a procedure known to correct the deficient processing of delF508-CFTR protein (26). The effect of salmeterol on the forskolin-activated chloride efflux was inhibited in the presence of a selective and competitive beta2-antagonist ICI-118551 (Fig. 1B, grey bars) or after incubation with the CFTR-inh172 (Fig. 1D, Sal + inh172), suggesting a specific beta2-adrenergic receptor stimulation and a CFTR-mediated chloride efflux. Nevertheless, we observed a residual chloride secretion which was not activated by amiloride and forskolin cocktail in untreated CF cells (Fig. 1A). It is possible that an alternative chloride channels 'such as $\mathrm{Ca}^{2+}$-activated 
chloride channels, coexist with CFTR in the apical plasmatic membrane, as previously described in airway epithelial cells $(8,27-29)$. To test this hypothesis, we performed SPQ experiments in the presence of either CFTR-inh172 (Fig. 1D, inh172), or 4'diisothiocynatostilbene-2,2'-disulfonic acid which is an inhibitor of the non-CFTR anion channel (Fig. 1D, DIDS), or in $\mathrm{Ca}^{2+}$-free medium (Fig. 1D, EGTA). As shown in figure 1D, inhibition, by $70 \%$, of the residual chloride secretion by $500 \mu \mathrm{M}$ DIDS or by chelation of extracellular $\mathrm{Ca}^{2+}$ by $10 \mathrm{mM}$ EGTA and the absence of inhibition by CFTR-inh172 suggest that non-CFTR chloride channels exist in CF serous cells.

Salmeterol increases the pool of delF508-CFTR at the apical pole of the human CF airway glandular epithelial monolayer and restores bioelectric properties- Using immunofluorescence and three-dimensional imaging, we obtained images of CFTR distribution in the non-CF serous cells and in the CF serous cells before and after a $24 \mathrm{~h}$ preincubation period in the presence of $200 \mathrm{nM}$ salmeterol. The subcellular distribution of CFTR is shown by the lateral image obtained from different $\mathrm{z}$ level images. In the non-CF serous cells, we observed a high staining at the apical pole (Fig 2A), which is consistent with the function of CFTR as an apical plasma membrane anion channel. In the CF serous cells, we observed the loss of the CFTR staining at the apical pole and a diffuse cytoplasmic staining (Fig. 2B), which is consistent with the inability of delF508-CFTR to accumulate at the plasma membrane. The incubation of CF cells with salmeterol induced higher apical staining of CFTR (Fig. 2C), which is consistent with the restoration of the forskolin-activated chloride efflux observed earlier.

We performed complementary Ussing chamber studies in CF cell monolayers. Six cultures of CF serous cells were studied, 3 of them were used as control and 3 were previously incubated for $24 \mathrm{~h}$ with $200 \mathrm{nM}$ salmeterol. The basal bioelectric properties at steady state were R: 
$212.3 \pm 10.4$ and $196.7 \pm 14.7 \Omega . \mathrm{cm}^{2} ;$ Isc: $7.3 \pm 3.6$ and $34.5 \pm 4.8 \mu \mathrm{A} / \mathrm{cm}^{2}$, for the control cells and the salmeterol-treated cells, respectively. Typical Isc tracing recorded from control cells and salmeterol-treated cells, showing the effects of addition of amiloride, forskolin and CFTR-inh172 is represented in figure 2D. Addition of amiloride did not cause significant changes in Isc in control CF cells and induced a decrease in Isc in salmeterol-treated CF cells, but the difference was not significant (Fig. 2E). Addition of forskolin induced a significantly greater increase $(\mathrm{p}<0.05)$ in Isc in salmeterol treated CF cells compared to untreated CF cells. Subsequent addition of the CFTR inhibitor CFTR-inh172 resulted in a significantly greater decrease $(\mathrm{p}<0.05)$ of Isc in salmeterol-treated CF cells compared to control CF cells (Fig. 2E), suggesting a specific CFTR-mediated chloride efflux.

Salmeterol did not induce persistent production of cAMP - We examined the effect of salmeterol on the signalling pathway by measuring intracellular cAMP concentration in $\mathrm{CF}$ serous cells. Under basal condition (Fig. 3A), salmeterol induced a rapid and transient $(\mathrm{t}=30$ min) increase in the intracellular cAMP level from $0.05 \mathrm{pmol} /$ well to $1.63 \mathrm{pmol} / \mathrm{well}$. This level was reduced to near normal at $24 \mathrm{~h}$ (0.06 pmol/well). After acute amiloride/forskolin stimulations ( $1 \mathrm{~min}$ ) and during salmeterol incubation (Fig. 3B), we observed an additional production of intracellular cAMP (10.72 pmol/well at $30 \mathrm{~min})$ suggesting that the cAMP production by serous cells via beta2-agonist stimulation did not reach its maximum capacity.

Salmeterol restored ion and water content inside CF secretory granules -The second part of this study was to examine if salmeterol could restore normal ion and water content in in situ secretory granules of CF serous cells. A typical X-ray spectrum acquired from an intracellular secretory granule is displayed in figure $4 \mathrm{~A}$. The results of X-ray microanalysis on secretory granules in cryosections of cells show that, compared to untreated CF cells (Fig. 4B, black 
bars), a $24 \mathrm{~h}$ pre-incubation period in the presence of salmeterol (Fig. 4B, white bars) significantly decreased $(\mathrm{p}<0.001)$ the $\mathrm{Na}^{+}$concentration $(6 \pm 2 \mathrm{mM}$ in salmeterol-treated versus $45 \pm 4 \mathrm{mM}$ in untreated $\mathrm{CF}$ cells $), \mathrm{Cl}^{-}$concentration $(21 \pm 3 \mathrm{mM}$ versus $59 \pm 4 \mathrm{mM})$ and $\mathrm{K}^{+}$concentration $(84 \pm 7 \mathrm{mM}$ versus $118 \pm 8 \mathrm{mM}$ ). In the same way, salmeterol induced a significant decrease $(\mathrm{p}<0.01)$ in the concentrations of $\mathrm{P}(106 \pm 10 \mathrm{mM})$ and $\mathrm{S}(59 \pm 1 \mathrm{mM})$ compared to the untreated CF cells $(170 \pm 10 \mathrm{mM}$ and $46 \pm 2 \mathrm{mM}$ respectively). The ion concentrations measured in the secretory granules of the salmeterol-treated CF cells were similar to those measured previously in the secretory granules of non-CF serous cells (15). Salmeterol did not modify significantly the cytoplasmic ion concentrations (data not shown).

To investigate the effect of salmeterol on secretory granule hydration, water content was determined by quantitative dark field imaging on freeze-dried cryosections of cells (15). Figure 5A displays a typical STEM dark field image of a CF-KM4 serous cell containing the nucleus delimited by nuclear envelope and the cytoplasm with numerous secretory granules. By image processing, we obtained a parametric image of water (Fig. 5B) in which the grey level of pixels is proportional to the mass water content. As shown in figure $5 \mathrm{C}$, we observed a significant increase $(\mathrm{p}<0.01)$ in the level of secretory granule hydration after the $24 \mathrm{~h}$ preincubation period of cells with salmeterol (Sal, $64 \pm 1 \%$ ) compared to the untreated CF cells (Untr, $59 \pm 1 \%$ ). No significant variation in ion concentration and hydration were observed in the cytoplasm of the CF serous cells in the presence or absence of salmeterol (data not shown). To provide evidence for the role of CFTR in the changes in secretory granule ion and water content after salmeterol exposure, we incubated the salmeterol-treated CF cells with 5 $\mu \mathrm{M}$ of CFTR-inh172 for $1 \mathrm{~h}$. We observed that CFTR-inh172 inhibited the effect of salmeterol on the ion concentration and the level of hydration in the CF secretory granules (Fig. 4B and 5C, grey bars), suggesting a CFTR-dependent mechanism of secretory granule homeostasis. 
Salmeterol restores normal CF secretory granule post-exocytosis expansion dynamics We examined the effect of a $24 \mathrm{~h}$ pre-incubation period in the presence of salmeterol on mucus post-exocytosis expansion dynamics by using phase-contrast videomicroscopy. We observed that the expansion index of the salmeterol-treated CF cells $(0.39 \pm 0.05)$ was significantly higher $(\mathrm{p}<0.01)$ compared to the untreated CF cells $(0.21 \pm 0.01)$. To provide evidence for the role of CFTR in the restoration of the granule content expansion process by salmeterol treatment, we incubated salmeterol-treated CF cells with $5 \mu \mathrm{M}$ of CFTR-inh172 for $1 \mathrm{~h}$ and we observed a significant $(\mathrm{p}<0.05)$ attenuation of the salmeterol effect, leading to a lower level of the post-exocytosis expansion dynamics of secretory granule content $(0.29 \pm$ 0.04). This result suggests that salmeterol treatment enhanced the secretory granule content expansion via a CFTR-dependent mechanism.

Isolated secretory granules express CFTR and lysozyme - We isolated secretory granules using a gradient of Percoll procedure to reduce osmotic damage and preserve granule integrity (25). The purity of granule preparation was evaluated by the observation with a transmission electron microscope. Figure 6A is an electron micrograph showing purified granules without detectable subcellular contaminants. Figures 6B and 6C present respectively lysosyme and CFTR western blot analysis of CF and non-CF isolated granules. An immonoreactive band referring to lysozyme, a secretory granule marker, is exhibited by both $\mathrm{CF}$ and non-CF isolated granules (fig 6B). Non-CF isolated secretory granules demonstrated immonoreactive bands corresponding to glycosylated CFTR whereas CF isolated secretory granules exhibited weaker immunoreactive bands (fig 6C).

Salmeterol restores secretory granule size -To study the effect of salmeterol on secretory granule size, we observed, by AFM, isolated granules from non-CF (Fig. 7A, B), CF (Fig. 7C, 
D) and salmeterol-treated CF cells (Fig. 7E, F). As shown in figure 7, the isolated granules had a rounded shape with a well defined edge. After image analysis using an auto-correlation function approach, we demonstrated that the mean diameter of the CF granules (102 $\pm 13 \mathrm{~nm})$ was significantly higher compared to the non-CF granules $(52 \pm 7 \mathrm{~nm})$ (Fig. 7G). When the CF serous cells were pre-incubated for $24 \mathrm{~h}$ with $200 \mathrm{nM}$ salmeterol, a significant $(\mathrm{p}<0.05)$ decrease of $18 \%$ in granule mean diameter $(84 \pm 5 \mathrm{~nm})$ was measured by AFM (Fig. 7G, CF + Sal). When the non-CF serous cells were pre-incubated for $1 \mathrm{~h}$ with $5 \mu \mathrm{M}$ of CFTR-inh172, a significant $(\mathrm{p}<0.05)$ increase of $20 \%$ in granule mean diameter $(62 \pm 2 \mathrm{~nm})$ was observed (Fig. 7G, non-CF + inh172). 


\section{Discussion}

In cystic fibrosis, a defective CFTR-mediated chloride efflux is reported to be associated with the failure of airway epithelial cells to secrete hydrated mucus. The beta2adrenergic receptor (beta2-AR) and CFTR, which are expressed in human airway epithelial cells, particularly in submucosal gland serous cells $(4,10,11)$, are two membrane-bound proteins linked through a PDZ-domain. This provides a plausible mechanism of activation of CFTR in airway epithelial cells in response to beta2-agonist stimulation. Nevertheless, CF airway epithelial cells have been reported to be unresponsive to short-acting beta-adrenergic agonist like isoproterenol (13). No data are available concerning the effects of a long-acting beta2-adrenergic agonist, such as salmeterol on the CFTR-dependent secretion capacity of human CF airway glandular cells homozygous for the delF508 mutation. CFTR is a protein kinase A-regulated chloride channel which we have previously shown to be involved in abnormal chloride secretion in CF tracheal gland serous cells (15). In the present study, we have demonstrated that salmeterol acts as a potent chloride secretagogue through the specific activation of beta2-AR and an accompanying CFTR-dependent mechanism. Previous studies have shown that short-acting beta2-agonists stimulates the beta2-AR, leading to elevation in cAMP levels and activation of protein kinase-A, and subsequently rapidly activates CFTR. The long-acting beta2-agonist salmeterol seems to behave differently without a fast activation of CFTR but induces an increase in forskolin-activated chloride secretion after several hours of incubation. The capacity of salmeterol to increase the stimulated-chloride secretion seems to be independent of sustained cAMP production. The role of the adenylate cyclase/PKA pathway is not clear because we observed a rapid and transient peak of cAMP following salmeterol incubation. This increase was no longer observed after $24 \mathrm{~h}$, a period identified with a maximal increase of the chloride secretion. It has been reported previously that 
salmeterol acting through a cAMP/PKA independent pathway, induced an increase of CFTR expression (11) and airway epithelial integrity (30) in non-CF human primary airway epithelial cells. Our results are in accordance with previous studies that showed that salmeterol activates beta2-ARthrough an exosite with nanomolar binding affinity and exhibits markedly prolonged duration of activity ( $>15 \mathrm{~h})$ despite removal of the drug and extensive washing (31-33). In contrast to short-acting beta2-adrenergic agonists, it was shown that salmeterol reduced the desensitisation and internalization of the beta2-AR in human bronchial epithelial cells (33). The persistent activation can be reversed by beta2-AR antagonists, as demonstrated by the effect of ICI-118551 on the chloride efflux. Salmeterol did not affect the level of CFTR mRNA (data not shown), as previously described in human primary airway epithelial cells (11), confirming that salmeterol exerts a post-transcriptional effect on CFTR. Two hypotheses could be considered to explain the increase of forskolin-stimulated chloride secretion and the accumulation of delF508-CFTR in the apical plasma membrane. First, salmeterol may act on the multistep process of misfolded CFTR degradation. Salmeterol could directly or indirectly act on the partitioning of CFTR through the ER by influencing the interaction of CFTR with chaperones, as described for thapsigargin (34), or by promoting folding of CFTR protein, as described for pharmacological chaperones like CFcor-325 (35). Second hypothesis, salmeterol may function by stabilizing the small amount of delF508CFTR at the cell surface. Both CFTR and beta2-AR, which are colocalized at the apical membrane of polarized serous cells like Calu-3 or MM39 cells, can bind the ezrin/radixin/NHERF1 (also referred to as ezrin-binding phosphoprotein 50, EBP50) macromolecular complex through their PDZ motifs. Therefore, persistent beta2-AR activation by salmeterol could result from the interaction of binding partners such as NHERF1, NHERF3 (also known as CFTR-associated protein 70, CAP70), protein kinase-A, ezrin and actin which might inhibit the fast endocytic retrieval of delF508-CFTR from the plasma 
membrane by facilitating the anchorage, stabilization or dimerization of CFTR (17). Nevertheless, salmeterol could act both by rescuing delF508-CFTR from ER and by enhancing its cell surface stability (36). Finally, all hypotheses are in agreement with the concept that delF508-CFTR can exit from the endoplasmic reticulum, be processed in the Golgi compartment and remained partially functional in CF airway epithelium. Moreover as suggested by Bebok et al. (37), permissive cell lines may not predict the responsiveness of delF508-CFTR by exogenous activating stimuli seen in more polarized systems, suggesting that beta2-AR stimulation may only be efficient in well-differentiated and polarized cells.

Many reports have been published on the ion concentrations in airway surface liquid in various species, including humans, and obtained using different analysis techniques $(38,39)$. The novelty of the present study was in determining ion and water content of native mucus inside the secretory granules, before its release into the collecting ducts. With this original analytic technique, we have previously shown that the ion and water content in secretory granules from CF glandular serous cells was abnormal compared to CF cells(15), while here we demonstrate for the first time that salmeterol partially reversed this anomaly, giving rise to a water level content intermediate between the level observed in $\mathrm{CF}$ and non-CF cells. We also showed rehydration of mucus inside the secretory granule via the action of salmeterol. Our results suggest the possible presence of ionic and water channels in serous secretory granules, which are consistent with those reported by Thevenod et al. who showed ion fluxes through potassium and chloride channels in the zymogen granule membrane (40), whereas Sugiya and Matsuki demonstrated that aquaporins were localized on the membrane of secretory granules isolated from the rat salivary parotid gland (41). The premise that the airway glandular acini are the source of fluid secretion has been confirmed by Wu et al (6) who reported that significant fluid secretion is missing in CF glands. We have previously 
shown that delF508-CFTR airway glandular cells exhibited a marked decrease in mucus postexocytosis expansion dynamics (15). Our findings are in agreement with those reported by Kuver et al (42) who demonstrated a low post-exocytotic mucus granule content expansion in cultured CFTR(-/-) gallbladder epithelial cells. Our results are also consistent with those reported by Leikauf et al. (43) and Kyle et al. (43) who showed, using submucosal gland mucous cells of cat and ferret, that beta2-agonist exposure induced enhancement of secretory granule exocytosis. In this study, we observed a difference in the size of the granule between non- $\mathrm{CF}$ and $\mathrm{CF}$ cells which is in accordance with the hypothesis of a granule intraluminal protein organization controlling granule homeostasis (44) and the necessity of ion channels, including aquaporins, for normal exocytotic release through secretory granule swelling (41). We provided evidence of the role of CFTR through the inhibitory effect of CFTR-inh172 and the presence of CFTR protein in isolated secretory granule membrane. These results are in agreement with reports of CFTR immunolabelling inside the serous secretory granules of human non-CF airway glandular tissue (45) and confocal laser immunofluorescence microscopy studies which revealed intracellular colocalization of mucins and CFTR in gallbladder epithelium, suggesting the presence of CFTR in secretory granule membrane (46).

In summary, our findings demonstrate the positive effect of the long acting beta2agonist salmeterol on efficient CFTR-mediated chloride secretion and the CFTR-dependent hydrated mucus exocytosis. We also report a relationship between CFTR-dependent mechanism of mucus hydration, mucus expansion dynamic and secretory granules size. In $\mathrm{CF}$, mucus dehydration is a major cause of impaired mucus transport that initiates bacterial colonization, infection and further airway mucus obstruction. The capacity of salmeterol to restore the chloride secretion and the hydration of the mucus inside the secretory granules of the airway glandular cells, in addition to its bronchodilatation effect, reinforce the hypothesis 
that salmeterol is able to improve pulmonary function and respiratory symptoms in $\mathrm{CF}$, as described previously in clinical trials in patients with mild to moderate CF (47).

\section{Acknowledgements}

This work is supported by the Institut National de la Santé et de la Recherche Médicale (INSERM), GlaxoSmithKline (UK) and by the French Association "Vaincre La Mucoviscidose". The authors thank Dr M. Merten (Vandoeuvre les Nancy, France) for providing the MM-39 and CF-KM4 cell lines, Laurence Worthman and Kamel Maouche for technical contribution and Malcolm W Johnson for editing and proofreading the manuscript. 


\section{Reference List}

1. Riordan JR, Rommens JM, Kerem B, Alon N, Rozmahel R, Grzelczak Z, Zielenski J, Lok S, Plavsic N, Chou JL, et al. Identification of the Cystic Fibrosis Gene: Cloning and Characterization of Complementary DNA. Science 1989;245:1066-1073.

2. Pilewski JM, Frizzell RA. How Do Cystic Fibrosis Transmembrane Conductance Regulator Mutations Produce Lung Disease? Curr Opin Pulm Med 1995;1:435-443.

3. Cheng SH, Rich DP, Marshall J, Gregory RJ, Welsh MJ, Smith AE. Phosphorylation of the R Domain by CAMP-Dependent Protein Kinase Regulates the CFTR Chloride Channel. Cell 1991;66:1027-1036.

4. Engelhardt JF, Yankaskas JR, Ernst SA, Yang Y, Marino CR, Boucher RC, Cohn JA, Wilson JM. Submucosal Glands Are the Predominant Site of CFTR Expression in the Human Bronchus. Nat Genet 1992;2:240-248.

5. Kreda SM, Mall M, Mengos A, Rochelle L, Yankaskas J, Riordan JR, Boucher RC. Characterization of Wild-Type and DeltaF508 Cystic Fibrosis Transmembrane Regulator in Human Respiratory Epithelia. Mol Biol Cell 2005;16:2154-2167.

6. Wu JV, Krouse ME, Wine JJ. Acinar Origin of CFTR-Dependent Airway Submucosal Gland Fluid Secretion. Am J Physiol Lung Cell Mol Physiol 2007;292:L304-L311.

7. Mills CL, Pereira MM, Dormer RL, McPherson MA. An Antibody Against a CFTRDerived Synthetic Peptide, Incorporated into Living Submandibular Cells, Inhibits Beta-Adrenergic Stimulation of Mucin Secretion. Biochem Biophys Res Commun 1992;188:1146-1152. 
8. Zhang AL, Roomans GM. Multiple Intracellular Pathways for Regulation of Chloride Secretion in Cultured Pig Tracheal Submucosal Gland Cells. Eur Respir J 1999;13:571-576.

9. Salathe M. Effects of Beta-Agonists on Airway Epithelial Cells. J Allergy Clin Immunol 2002;110:S275-S281.

10. Carstairs JR, Nimmo AJ, Barnes PJ. Autoradiographic Visualization of BetaAdrenoceptor Subtypes in Human Lung. Am Rev Respir Dis 1985;132:541-547.

11. Taouil K, Hinnrasky J, Hologne C, Corlieu P, Klossek JM, Puchelle E. Stimulation of Beta 2-Adrenergic Receptor Increases Cystic Fibrosis Transmembrane Conductance Regulator Expression in Human Airway Epithelial Cells Through a CAMP/Protein Kinase A-Independent Pathway. J Biol Chem 2003;278:17320-17327.

12. Naren AP, Cobb B, Li C, Roy K, Nelson D, Heda GD, Liao J, Kirk KL, Sorscher EJ, Hanrahan J, et al. A Macromolecular Complex of Beta 2 Adrenergic Receptor, CFTR, and Ezrin/Radixin/Moesin-Binding Phosphoprotein 50 Is Regulated by PKA. Proc Natl Acad Sci U S A 2003;100:342-346.

13. Willumsen NJ, Boucher RC. Activation of an Apical Cl- Conductance by $\mathrm{Ca} 2+$ Ionophores in Cystic Fibrosis Airway Epithelia. Am J Physiol 1989;256:C226-C233.

14. Widdicombe JH. Cystic Fibrosis and Beta-Adrenergic Response of Airway Epithelial Cell Cultures. Am J Physiol 1986;251:R818-R822.

15. Baconnais S, Delavoie F, Zahm JM, Milliot M, Terryn C, Castillon N, Banchet V, Michel J, Danos O, Merten M, et al. Abnormal Ion Content, Hydration and Granule 
Expansion of the Secretory Granules From Cystic Fibrosis Airway Glandular Cells. Exp Cell Res 2005;309:296-304.

16. Proesmans M, Vermeulen F, De Boeck K. What's New in Cystic Fibrosis? From Treating Symptoms to Correction of the Basic Defect. Eur J Pediatr 2008.

17. Kammouni W, Moreau B, Becq F, Saleh A, Pavirani A, Figarella C, Merten MD. A Cystic Fibrosis Tracheal Gland Cell Line, CF-KM4. Correction by AdenovirusMediated CFTR Gene Transfer. Am J Respir Cell Mol Biol 1999;20:684-691.

18. Merten MD, Kammouni W, Renaud W, Birg F, Mattei MG, Figarella C. A Transformed Human Tracheal Gland Cell Line, MM-39, That Retains Serous Secretory Functions. Am J Respir Cell Mol Biol 1996;15:520-528.

19. Drury DE, Chong LK, Ghahramani P, Peachell PT. Influence of Receptor Reserve on Beta-Adrenoceptor-Mediated Responses in Human Lung Mast Cells. Br J Pharmacol 1998;124:711-718.

20. Thiagarajah JR, Song Y, Haggie PM, Verkman AS. A Small Molecule CFTR Inhibitor Produces Cystic Fibrosis-Like Submucosal Gland Fluid Secretions in Normal Airways. FASEB J 2004;18:875-877.

21. Bonnet N, Zahm JM. Analysis of Image Sequences in Fluorescence Videomicroscopy of Stationary Objects. Cytometry 1998;31:217-228.

22. Baconnais S, Tirouvanziam R, Zahm JM, de Bentzmann S, Peault B, Balossier G, Puchelle E. Ion Composition and Rheology of Airway Liquid From Cystic Fibrosis Fetal Tracheal Xenografts. Am J Respir Cell Mol Biol 1999;20:605-611. 
23. Zierold K. The Determination of Wet Weight Concentrations of Elements in FreezeDried Cryosections From Biological Cells. Scan Electron Microsc 1986:713-724.

24. Zierold K. Effects of Cadmium on Electrolyte Ions in Cultured Rat Hepatocytes Studied by X-Ray Microanalysis of Cryosections. Toxicol Appl Pharmacol 1997;144:70-76.

25. De Lisle RC, Schulz I, Tyrakowski T, Haase W, Hopfer U. Isolation of Stable Pancreatic Zymogen Granules. Am J Physiol 1984;246:G411-G418.

26. Denning GM, Anderson MP, Amara JF, Marshall J, Smith AE, Welsh MJ. Processing of Mutant Cystic Fibrosis Transmembrane Conductance Regulator Is TemperatureSensitive. Nature 1992;358:761-764.

27. Jiang C, Finkbeiner WE, Widdicombe JH, Miller SS. Fluid Transport Across Cultures of Human Tracheal Glands Is Altered in Cystic Fibrosis. J Physiol 1997;501 ( Pt 3):637-647.

28. Tarran R, Loewen ME, Paradiso AM, Olsen JC, Gray MA, Argent BE, Boucher RC, Gabriel SE. Regulation of Murine Airway Surface Liquid Volume by CFTR and Ca2+-Activated Cl- Conductances. J Gen Physiol 2002;120:407-418.

29. MacVinish LJ, Cope G, Ropenga A, Cuthbert AW. Chloride Transporting Capability of Calu-3 Epithelia Following Persistent Knockdown of the Cystic Fibrosis Transmembrane Conductance Regulator, CFTR. Br J Pharmacol 2007;150:10551065. 
30. Coraux C, Kileztky C, Polette M, Hinnrasky J, Zahm JM, Devillier P, de Bentzmann S, Puchelle E. Airway Epithelial Integrity Is Protected by a Long-Acting Beta2Adrenergic Receptor Agonist. Am J Respir Cell Mol Biol 2004;30:605-612.

31. Green SA, Spasoff AP, Coleman RA, Johnson M, Liggett SB. Sustained Activation of a G Protein-Coupled Receptor Via "Anchored" Agonist Binding. Molecular Localization of the Salmeterol Exosite Within the 2-Adrenergic Receptor. J Biol Chem 1996;271:24029-24035.

32. Moore RH, Millman EE, Godines V, Hanania NA, Tran TM, Peng H, Dickey BF, Knoll BJ, Clark RB. Salmeterol Stimulation Dissociates Beta2-Adrenergic Receptor Phosphorylation and Internalization. Am J Respir Cell Mol Biol 2007;36:254-261.

33. January B, Seibold A, Allal C, Whaley BS, Knoll BJ, Moore RH, Dickey BF, Barber R, Clark RB. Salmeterol-Induced Desensitization, Internalization and Phosphorylation of the Human Beta2-Adrenoceptor. Br J Pharmacol 1998;123:701-711.

34. Egan ME, Calcium-pump inhibitors induce functional surface expression of DeltaF508-CFTR protein in cystic fibrosis epithelial cells. Nat Med 2002; 8:485-492.

35. Loo W., Bartlett C., Clarke D. Correctors promote folding of the CFTR in the endoplasmic reticulum. Biochem J 2008; 413:29-36.

36. Varga K, Goldstein RF, Jurkuvenaite A, Chen L, Matalon S, Sorscher EJ, Bebok Z, Collawn JF. Enhanced cell-surface stability of rescued DeltaF508 cystic fibrosis transmembrane conductance regulator (CFTR) by pharmacological chaperones. Biochem J. 2008;410(3):555-64. 
37. Bebok Z, Collawn JF, Wakefield J, Parker W, Li Y, Varga K, Sorscher EJ, Clancy JP. Failure of CAMP Agonists to Activate Rescued DeltaF508 CFTR in CFBE41oAirway Epithelial Monolayers. J Physiol 2005;569:601-615.

38. Knowles MR, Robinson JM, Wood RE, Pue CA, Mentz WM, Wager GC, Gatzy JT, Boucher RC. Ion Composition of Airway Surface Liquid of Patients With Cystic Fibrosis As Compared With Normal and Disease-Control Subjects. J Clin Invest 1997;100:2588-2595.

39. Zahm JM, Baconnais S, Davidson DJ, Webb S, Dorin J, Bonnet N, Balossier G, Puchelle E. X-Ray Microanalysis of Airway Surface Liquid Collected in Cystic Fibrosis Mice. Am J Physiol Lung Cell Mol Physiol 2001;281:L309-L313.

40. Thevenod F. Ion Channels in Secretory Granules of the Pancreas and Their Role in Exocytosis and Release of Secretory Proteins. Am J Physiol Cell Physiol 2002;283:C651-C672.

41. Sugiya H, Matsuki M. AQPs and Control of Vesicle Volume in Secretory Cells. $J$ Membr Biol 2006;210:155-159.

42. Kuver R, Klinkspoor JH, Osborne WR, Lee SP. Mucous Granule Exocytosis and CFTR Expression in Gallbladder Epithelium. Glycobiology 2000;10:149-157.

43. Leikauf GD, Ueki IF, Nadel JA. Autonomic Regulation of Viscoelasticity of Cat Tracheal Gland Secretions. J Appl Physiol 1984;56:426-430.

44. Perez-Vilar J. Mucin Granule Intraluminal Organization. Am J Respir Cell Mol Biol 2007;36:183-190. 
45. Jacquot J, Puchelle E, Hinnrasky J, Fuchey C, Bettinger C, Spilmont C, Bonnet N, Dieterle A, Dreyer D, Pavirani A, et al. Localization of the Cystic Fibrosis Transmembrane Conductance Regulator in Airway Secretory Glands. Eur Respir J 1993;6:169-176.

46. Kuver R, Wong T, Klinkspoor JH, Lee SP. Absence of CFTR Is Associated With Pleiotropic Effects on Mucins in Mouse Gallbladder Epithelial Cells. Am J Physiol Gastrointest Liver Physiol 2006;291:G1148-G1154.

47. Hordvik NL, Sammut PH, Judy CG, Colombo JL. Effectiveness and Tolerability of High-Dose Salmeterol in Cystic Fibrosis. Pediatr Pulmonol 2002;34:287-296.

\begin{abstract}
Abbreviations: AFM, atomic force microscopy; beta2-AR, beta2-adrenergic receptor cAMP, cyclic adenosine monophosphate; $\mathrm{CF}$, cystic fibrosis; CFTR, CF transmembrane conductance regulator; EGTA, ethyleneglycol-bis-(beta-aminoethyl ether)- $N, N^{\prime}$-tetraacetic acid; DIDS, 4'-diisothiocynatostilbene-2,2'-disulfonic acid; NHERF, sodium-hydrogen exchanger regulatory factor; SPQ, 6-methoxy-N-(3sulfopropyl)quinolinium; STEM, scanning transmission electron microscopy; TEM transmission electron microscopy; Untr, untreated; wt, wild type.
\end{abstract}




\section{FIGURES LEGENDS}

Fig. 1. Salmeterol restores the forskolin-activated chloride secretion. . (A) Representative greyscale fluorescent images of SPQ-loaded salmeterol-treated CF-KM4 glandular serous cells and typical time-dependent SPQ fluorescence variations showing increased chloride efflux in salmeterol-treated $(200 \mathrm{nM}) \mathrm{CF}$ cells after $10 \mu \mathrm{M}$ amiloride (aml) and $25 \mu \mathrm{M}$ forkolin (fsk) exposure. (B) A dose-dependent effect of salmeterol on forskolin-activated chloride secretion was observed (white bars) and this effect was inhibited by co-incubation with the beta2-antagonist ICI-118551 (grey bars). (C) Time-dependent effect of $200 \mathrm{nM}$ salmeterol on forskolin-activated chloride secretion (4 h, $16 \mathrm{~h}$ and $24 \mathrm{~h}$ ) compared to cells maintained at $27^{\circ} \mathrm{C}$ for $24 \mathrm{~h}$. (D) Specific effect of $200 \mathrm{nM}$ salmeterol on forskolin-activated chloride secretion. CF-KM4 cells were incubated with $500 \mu \mathrm{M}$ DIDS (DIDS), in free-Ca ${ }^{2+}$ medium (EGTA), with $5 \mu$ M CFTR-inh172 for $1 \mathrm{~h}$ (inh172), $200 \mathrm{nM}$ salmeterol for $24 \mathrm{~h}$ (Sal) or $200 \mathrm{nM}$ salmeterol for $24 \mathrm{~h}$ then $5 \mu \mathrm{M}$ CFTR-inh172 for $1 \mathrm{~h}(\mathrm{Sal}+\mathrm{inh} 172) .(* * * \mathrm{p}<0.001$, $* * \mathrm{p}<0.01)$. Untr, untreated.

Fig. 2. Salmeterol increased the pool of delF508-CFTR at the apical membrane and restores bioelectric properties. Subcellular distribution of CFTR immunostaining (A) In non-CF cells, CFTR immunostaining was detected at the apical level of cells. (B) In CF cells, a diffuse intracellular staining was observed. (C) In salmeterol-treated CF cells, we noted an apical staining of CFTR similar to the non-CF staining. (D) Typical recordings of short circuit current measured on glandular serous cells in an Ussing chamber. Amiloride, forskolin and CFTR inhibitor were added to the apical compartment. (E) Forskolin significantly increased the short circuit current and this increase was inhibited by CFTR inhibitor. Data correspond to 
triplicate experiments and are expressed as mean \pm standard deviation of the mean $(* \mathrm{p}<$ $0.05)$.

Fig. 3. Salmeterol did not induce a persistent cAMP production. Intracellular cAMP in salmeterol-treated CF serous cells was analysed using a cAMP immunologic assay (A) in basal condition and (B) after acute amiloride/forskolin stimulations. Salmeterol induced a rapid and transient increase in cAMP level. However, the both pathway of adenylate activation by beta2-agonsit and forskolin induced a higher transient increase in cAMP level. Data correspond to triplicate experiments.

Fig. 4. Intracellular ion composition after salmeterol treatment. (A) Typical x-ray spectrum acquired from an intracellular secretory granule of CF-KM4 glandular serous cells. (B) Ion concentrations in the CF secretory granules in the absence (Untr) or presence of 200 $\mathrm{nM}$ salmeterol for $24 \mathrm{~h}$ (Sal) or with $5 \mu \mathrm{M}$ CFTR-inh172. Salmeterol significantly reduced the $\mathrm{Na}, \mathrm{P}, \mathrm{S}, \mathrm{Cl}$ and $\mathrm{K}$ concentration in secretory granules and this decrease was abolished by CFTR inhibitor. According to the different experimental conditions, 49 to 65 secretory granules from 14 to 21 cells were analysed. Data are expressed as mean \pm standard deviation of the mean $(* * * \mathrm{p}<0.001, * * \mathrm{p}<0.01, * \mathrm{p}<0.05)$.

Fig. 5. Intracellular water content after salmeterol treatment. (A) Typical CF-KM4 glandular serous cells observed by dark field in a STEM microscope. Numerous secretory granules are observed within the cytoplasm.. (B) Parametric image of water obtain after image processing in which the pixel grey levels are proportional to the mass water content (from 50 $\%$ to $100 \%$ of water). (C) Salmeterol significantly increased the water content in CF secretory granules and this increase was inhibited by CFTR-inh172. According to the 
different experimental conditions, 36 to 65 secretory granules from at least 14 to 16 cells were analysed. Data are expressed as mean \pm standard deviation of the mean $(* * p<0.01)$.

Fig. 6. Isolation of secretory granules. (A) Electron micrograph showing the purity of isolated granules embedded in EPON. (B) Lysosyme and (C) CFTR western blotting from non-CF and $\mathrm{CF}$ isolated secretory granules.

Fig. 7. Topographic images and size of isolated secretory granules. Surface topography and three-dimensional images obtained by tapping-mode in AFM from isolated secretory granules of the non-CF $(\mathbf{A}, \mathbf{B}), \mathrm{CF}(\mathbf{C}, \mathbf{D})$ and salmeterol-treated CF cells $(\mathbf{E}, \mathbf{F})$. (G) The mean diameter of the isolated secretory granules from CF cells, measured from these images, was significantly higher than in non-CF cells and significantly reduced by salmeterol treatment $(* * \mathrm{p}<0.01, * \mathrm{p}<0.05)$. 
Figure 1
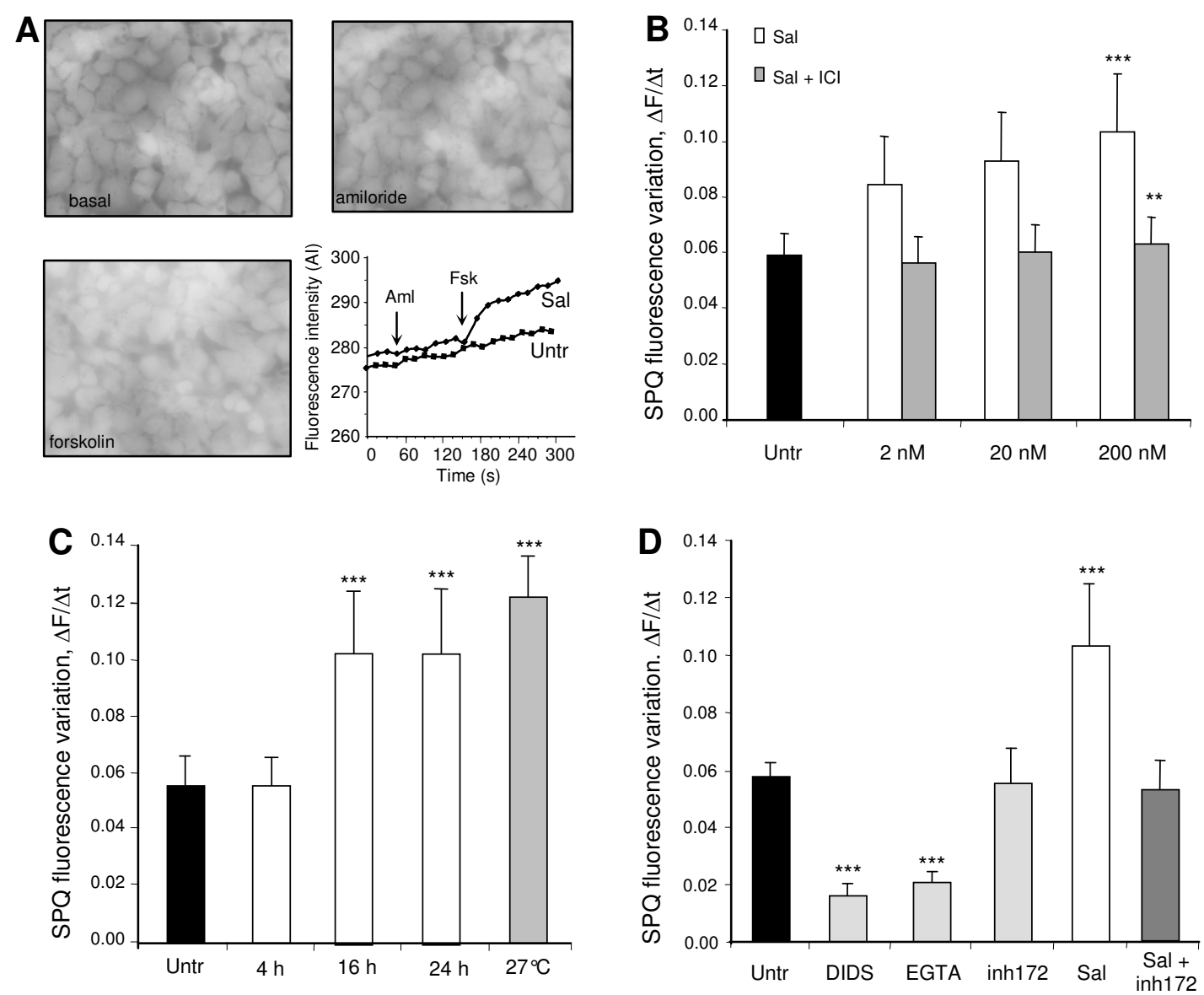
Figure 2
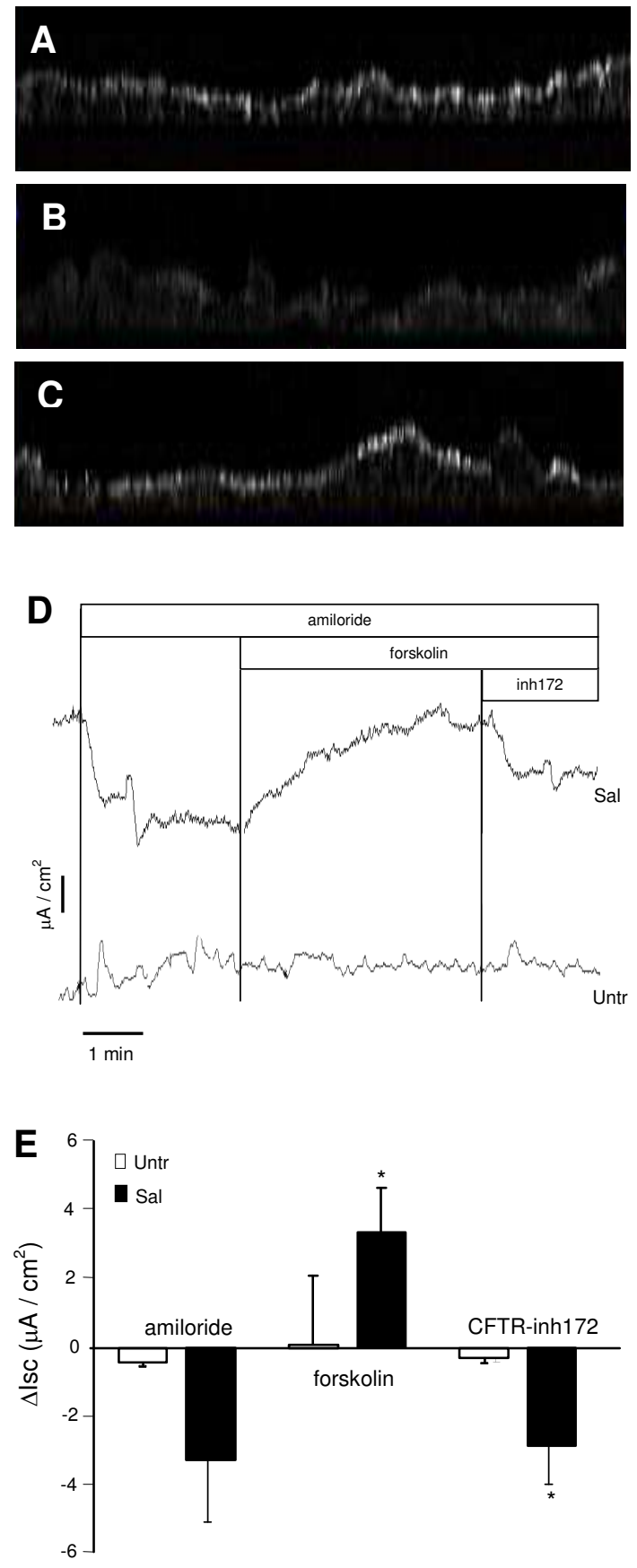


\section{Page 35 of 39}

Figure 3
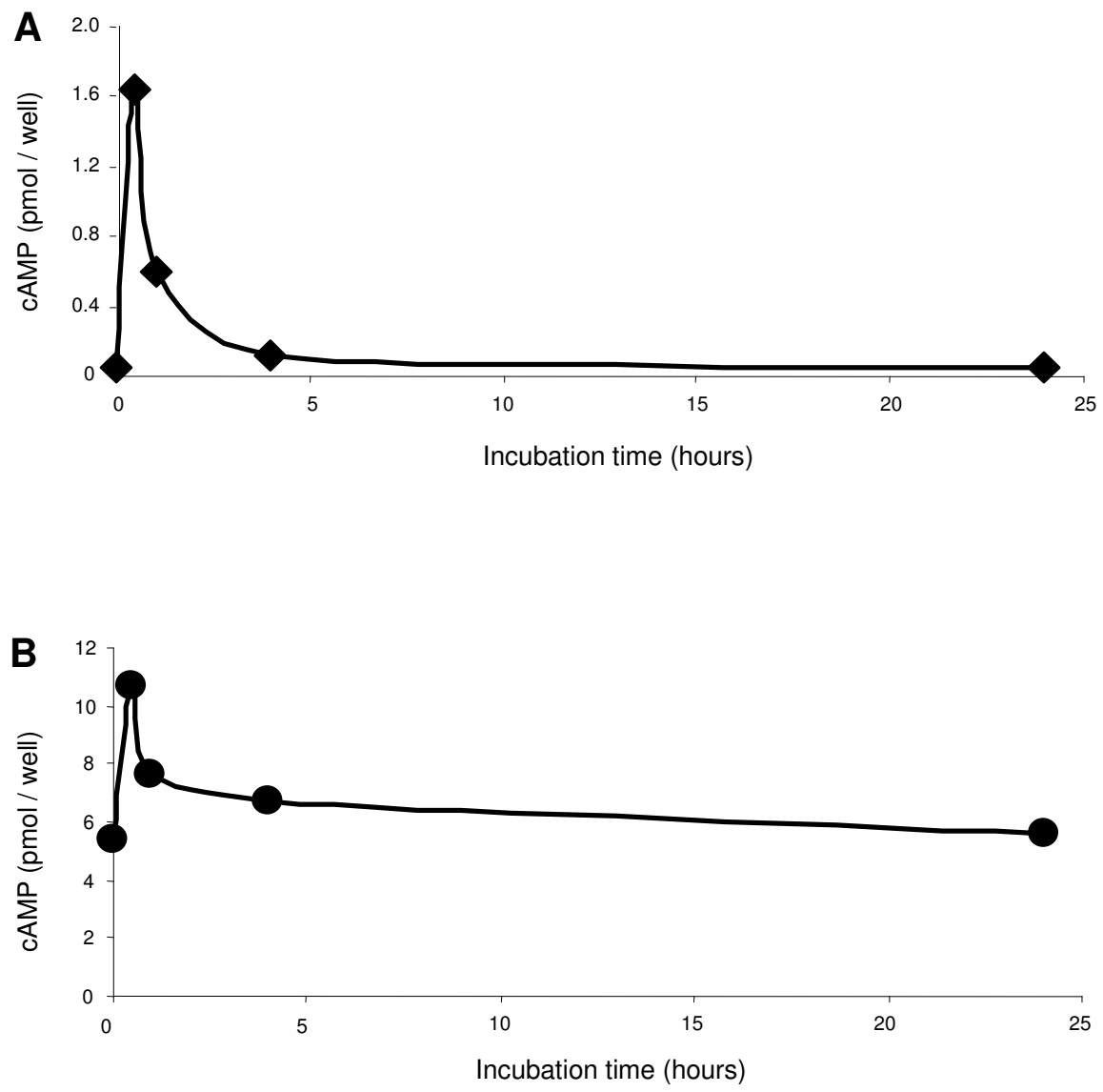
Figure 4
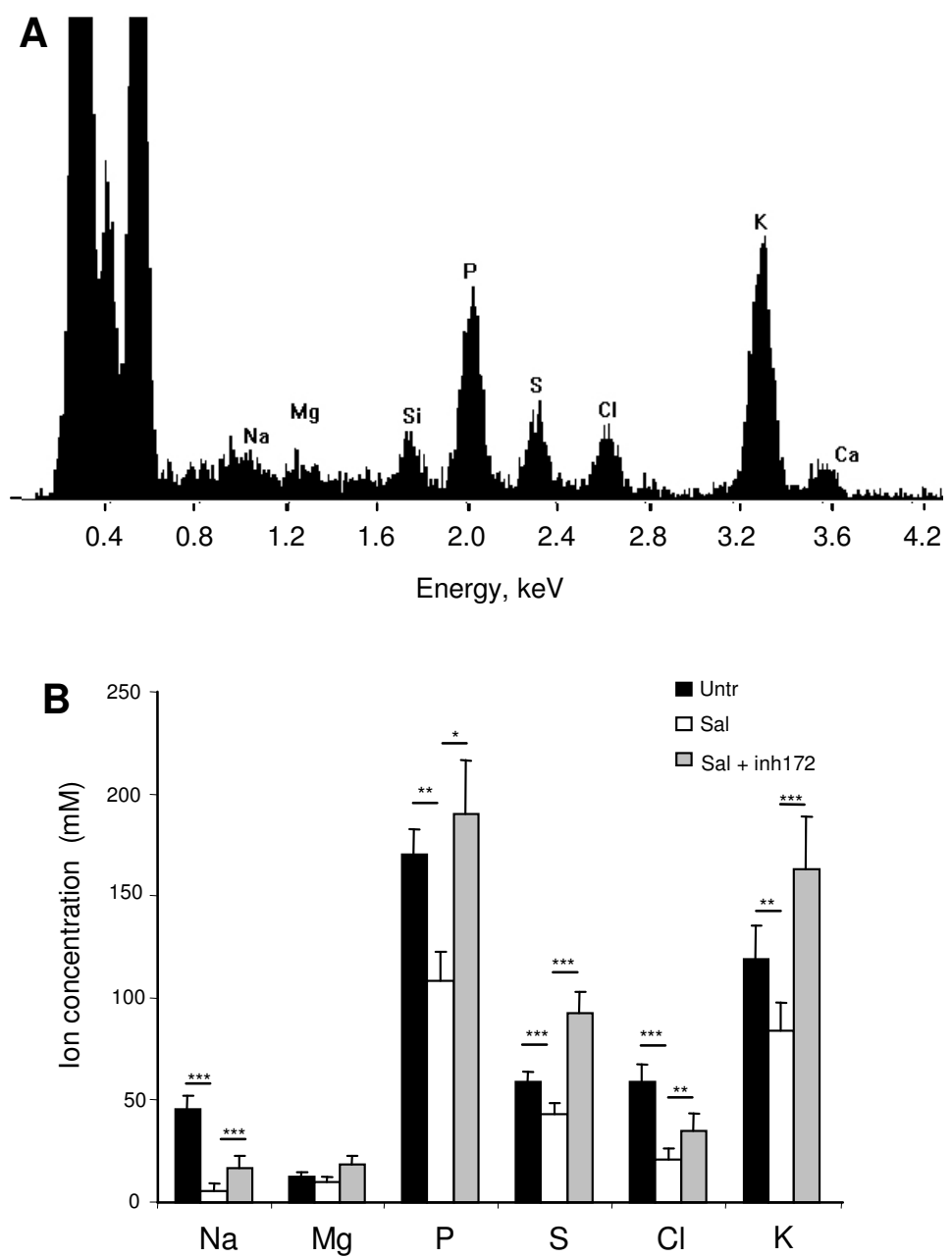
Figure 5
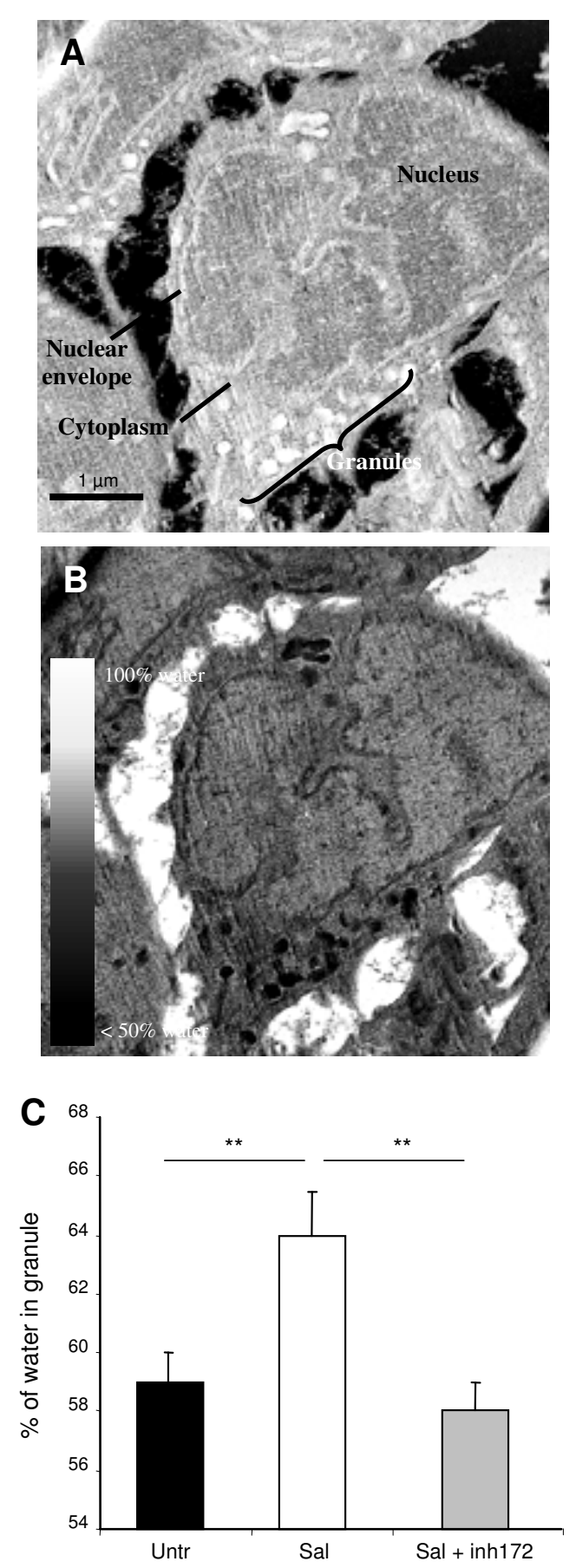
Figure 6

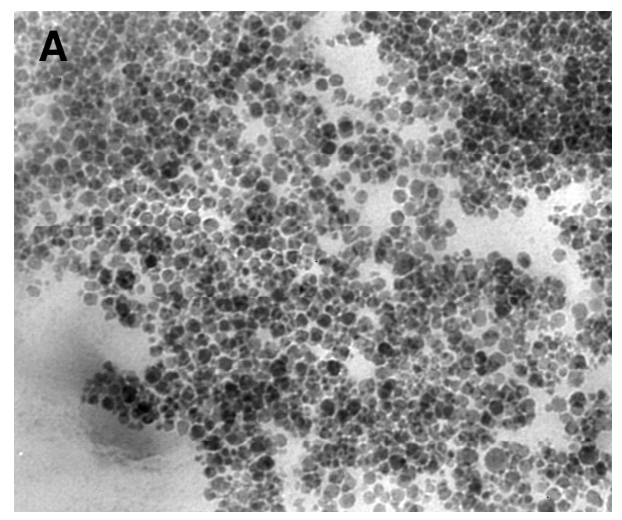

B

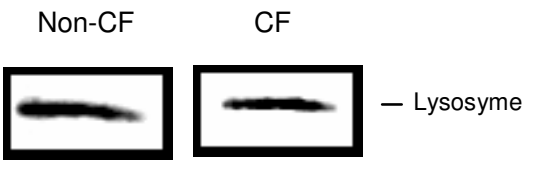

C

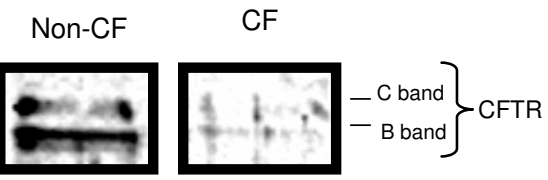




\section{Page 39 of 39}

Figure 7
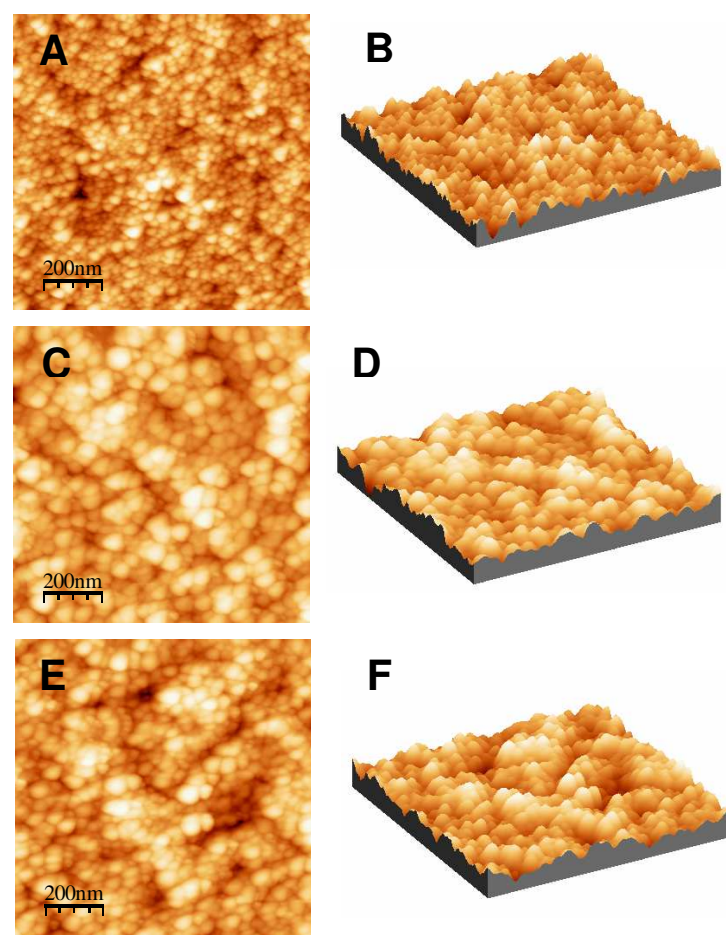

F
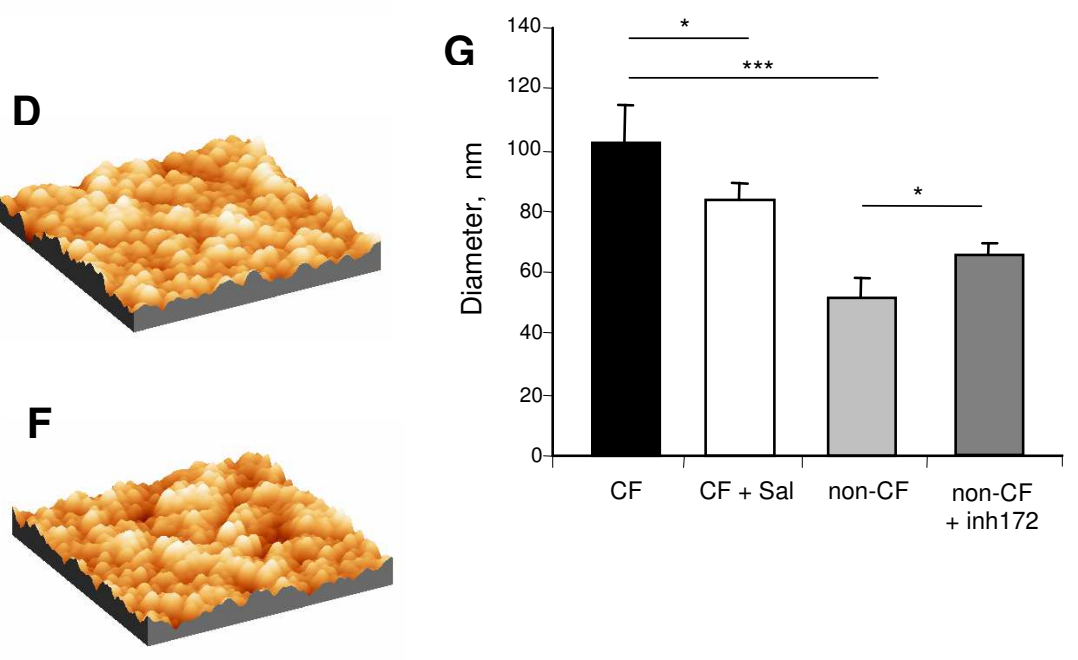